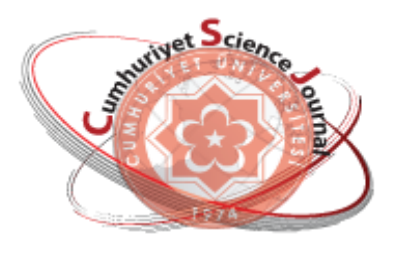

e-ISSN: $2587-246 X$

ISSN : 2587-2680

\section{Cuculaniyet Seionce Journal $\operatorname{csg}$}

Cumhuriyet Sci. J., Vol.40-1(2019) 136-140

\title{
Determination of Glutathione Reductase Activity Changes Exposed to Some 2-Aminothiazole Derivatives
}

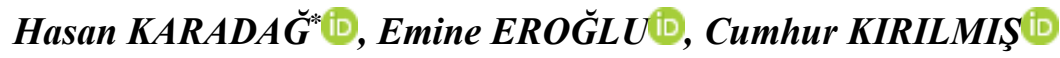 \\ Adiyaman University, Science and Letters Faculty, Chemistry Department, Adiyaman, TURKEY \\ Received: 28.12.2018; Accepted: 05.02.2019 \\ http://dx.doi.org/10.17776/csj.504690
}

\begin{abstract}
In this work, effects of concentrations ranging from 0 to $500 \mathrm{mg} / \mathrm{L}$ of some 2-aminothiazole derivatives such as 4,4'-(disulfanediylbis(methylene))bis(thiazol-2-amine) dihyrochloride (DMTA) and 2amino-4-(chloromethyl)thiazole hydrochloride (ACT) on glutathione reductase from baker's yeast (Saccharomyces cerevisiae) (GR) were investigated. With exposure of $25,50,100,250$ and $500 \mathrm{mg} / \mathrm{L}$ concentrations, \% GR activity changes were calculated as $-5.29 ;-3.85 ;-2.40 ;-6.73$ and -10.58 in DMTA applications, while these changes were calculated as $+0.98 ; 0.00 ;-0.49 ;-2.45$ and 0.00 in ACT applications, respectively. This work indicated that there was a slight decrease in GR activity with the increase of DMTA concentrations and there was no significant change in GR activity with the increase of ACT concentrations. But according to control activities, no statitistical changes were observed in GR activities with exposure of these 2aminothiazole derivatives $(\mathrm{p}>0.05, \mathrm{n}=3)$.
\end{abstract}

Keywords: Glutathione Reductase, 2-Aminothiazole, 4,4'-(disulfanediylbis(methylene)) bis(thiazol-2-amine) dihyrochloride, 2-amino-4-(chloromethyl)thiazole hydrochloride.

\section{Bazı 2-aminotiazol Türevlerine Maruz Kalmış Glutatyon Redüktaz Aktivitesindeki Değişimlerinin Belirlenmesi}

\begin{abstract}
Özet. Bu çalışmada, 2-Aminotiazol türevleri olan 4,4'-(disulfanediylbis(methylene))bis(thiazol-2-amine) dihyrochloride (DMTA) ve 2-amino-4-(chloromethyl)thiazole hydrochloride (ACT)'in 0 dan $500 \mathrm{mg} / \mathrm{L}$ ye değişen derişimlerinin ekmek mayası (Saccharomyces cerevisiae) glutatyon redüktazı (GR) üzerine olan etkileri araştırılmıştır. 25, 50, 100, 250 ve $500 \mathrm{mg} / \mathrm{L}$ derişimlere maruz bırakılma ile \% GR aktivitesindeki değişimler, DMTA uygulamalarında sirasıyla $-5,29 ;-3,85 ;-2,40 ;-6,73$ ve $-10,58$ olarak hesaplanırken, ACT uygulamalarında sırasıyla $+0,98 ; 0,00 ;-0,49 ;-2,45$ ve 0,00 olarak hesaplanmıştır. Bu çalışma, DMTA derişimlerinin artışı ile GR aktivitesinde hafif bir düşüş olduğunu ve ACT derişimlerinin artışı ile GR aktivitesinde önemli bir değişimin olmadığını göstermiş̧ir. Ancak kontrol aktivitelerine göre, bu 2-aminotiazol türevlerinin etkileştiği GR aktivitelerinde herhangi bir istatistiksel değişim gözlemlenmemiştir $\quad(p>0,05, n=$ $3)$.
\end{abstract}

Anahtar Kelimeler: Glutatyon Redüktaz, 2-Aminotiazol, 4,4'-(disulfanediylbis(methylene)) bis(thiazol-2amine) dihyrochloride, 2-amino-4-(chloromethyl)thiazole hydrochloride.

\section{INTRODUCTION}

2-Aminothiazole derivatives have a heterocyclic ring system and have antiviral [1], antimicrobial [2], anticancer [3] and anti-inflammatory [4] activities. Recent research has shown that 2- aminothiazole derivatives act as inhibitors against kynurenine-3-hydroxylase and cyclin-dependent kinase enzymes [5]. 
Glutathione reductase (EC 1.8.1.7) (GR) acts an antioxidant. GR converts oxidized glutathione (GSSG) to form reduced glutathione (GSH) in the presence of NADPH ( $\beta$-Nicotinamide adenine dinucleotide 2'-phosphate reduced) [6].

$$
\mathrm{GSSG}+\mathrm{NADPH}+\mathrm{H}^{+} \stackrel{\mathrm{GR}}{\longrightarrow} 2 \mathrm{GSH}+\mathrm{NADP}^{+}
$$

GSSG contains disulfide bridge (-S-S-) in its structure. DMTA contains disulfide bridges such as GSSG, which is the substrate of the GR enzyme. DMTA has the potential to make inhibition due to this feature. If inhibition occurs, GSH will not occur. GSH has important functions in metabolism. GSH plays a key role in maintaining proper functions in human cells and preventing oxidative stress. It neutralizes hydroxyl radicals, singlet oxygen and various electrophiles [7]. ACT is a 2aminothiazole derivative without disulfide bridge. In this study, we investigated whether 2aminothiazole derivative compounds containing disulfide bridge and no disulfide bridge affect on GR.

\section{MATERIALS AND METHODS}

\subsection{Chemicals}

4,4'-(disulfanediylbis(methylene))bis(thiazol-2amine) dihyrochloride (Fig.1a) was received from Dr. Cumhur KIRILMIŞ [8]. 2-Amino-4(chloromethyl)thiazole hydrochloride (SYX00295) (Fig.1b), L-Glutathione oxidized (G4501), $\beta$-Nicotinamide adenine dinucleotide 2'phosphate reduced tetrasodium salt hydrate (N1630), Glutathione reductase from baker's yeast (S. cerevisiae) (G3664) were received from SigmaAldrich. Other chemicals used were analytical grade.

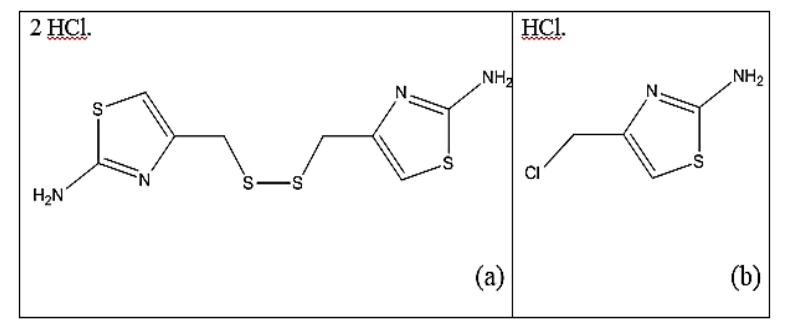

Figure 1. Structures of 4,4'(disulfanediylbis(methylene))bis(thiazol-2-amine) dihyrochloride (a) and 2-amino-4-(chloromethyl)thiazole hydrochloride (b).

\subsection{Protein determination}

The protein concentration of GR was measured spectrophotometrically at $750 \mathrm{~nm}$ [9]. Bovine serum albumin was used as standard for the determination of GR protein concentration. For determination of protein concentration, four solutions were prepared. 1. Solution (A): $0.5 \mathrm{~g}$ CuSO4.5 $\mathrm{H} 2 \mathrm{O}$ and $1 \mathrm{~g}$ sodium citrate dihydrate were dissolved at distilled water and completed to $100 \mathrm{~mL}$ by distilled water. 2. Solution (B): $2 \mathrm{~g}$ $\mathrm{Na} 2 \mathrm{CO} 3$ and $0.4 \mathrm{~g} \mathrm{NaOH}$ were dissolved at distilled water and completed to $100 \mathrm{~mL}$ by distilled water. 3. Solution (C): $2 \mathrm{~mL}$ solution A was added to $100 \mathrm{~mL}$ solution B. 4. Solution (D): $20 \mathrm{~mL}$ Folin-Ciocalteu was added to $20 \mathrm{~mL}$ distilled water. After preparation of these four solutions, $2.5 \mathrm{~mL}$ solution $\mathrm{C}$ was added to $0.5 \mathrm{~mL}$ of GR solution, shaked, waited for 10 minutes at room temperature, then added $0.25 \mathrm{~mL}$ of solution $\mathrm{D}$, shaked, waited for 30 minutes and read at 750 $\mathrm{nm}$ for determination of GR concentration.

\subsection{Glutathione reductase activitiy}

The enzyme activity was measured spectrophotometrically by reading the changes in absorbance at $340 \mathrm{~nm}$ during oxidation of NADPH to $\mathrm{NADP}^{+}$by GSSG at $37{ }^{\circ} \mathrm{C}$ at incubated UV1800 UV-VIS Spectrophotometer (Shimadzu Scientific Instruments) [10]. The reaction solution was contained: $1.0 \mathrm{mM}$ GSSG, $0.12 \mathrm{mM}$ NADPH, $0.10 \mathrm{M}$ potassium phosphate buffer ( $\mathrm{pH}$ 7.6). The oxidation of $1 \mu \mathrm{mol}$ of NADPH/minute under these conditions was used as a Unit (U) of GR activity. Milimolar extinction coefficient of $\beta$ - NADPH at $340 \mathrm{~nm}$ was used as 6.22 . The specific activity of GR was indicated as $\mathrm{U} / \mathrm{mg}$ protein.

\subsection{Effect of 2-aminothiazole derivatives on enzyme activity}

Solutions of $5000 \mathrm{mg} / \mathrm{L}$ DMTA and ACT in distilled water were prepared. After that, arrangement of $0,25,50,100,250$ and $500 \mathrm{mg} / \mathrm{L}$ DMTA and ACT with distilled water and $700 \mu \mathrm{L}$ GR solution were done [11]. At control or $0 \mathrm{mg} / \mathrm{L}$, $300 \mu \mathrm{L}$ distilled water and $700 \mu \mathrm{L}$ GR solution were used. Solution volume of enzyme and 
distilled water and 2-aminothiazole derivative was $1 \mathrm{~mL}$. The mixture of GR and distilled water and 2-aminothiazole derivative was waited at room temperature for 10 minutes. Then activities of GR were determined.

\subsection{Value analysis}

The obtained values were shown as mean \pm standard deviation. For the statistical analyses, oneway analysis of variance (ANOVA) was used, followed by the Student Newman-Keul's test using the IBM SPSS version 22 statistical software (SPSS Inc. Chicago, IL, USA). Differences were considered as significant if $\mathrm{p}<0.05$.

\section{RESULTS AND DISCUSSION}

\section{1. \\ Effect \\ of}

(disulfanediylbis(methylene))bis(thiazol-2amine) dihyrochloride on glutathione reductase activity

GR activities exposed to solutions of DMTA from 0 to $500 \mathrm{mg} / \mathrm{L}$ were measured. Mean of enzyme activity and standard deviation values were given in Table 1. Activity-concentration graph was shown in Fig. 2. When Table 1 and Fig.2 were examined, it was observed that there was a slight decrease in GR enzyme activity while DMTA concentration increased. However, no statistically significant changes were observed when compared to control group ( $\mathrm{p}>0.05, \mathrm{n}=3$ ). The percent changes in GR enzyme activities exposed to 25, 50, 100,250 and $500 \mathrm{mg} / \mathrm{L}$ of DMTA were calculated as $-5.29 ;-3.85 ;-2,40 ; \quad-6.73$ and -10.58 respectively.

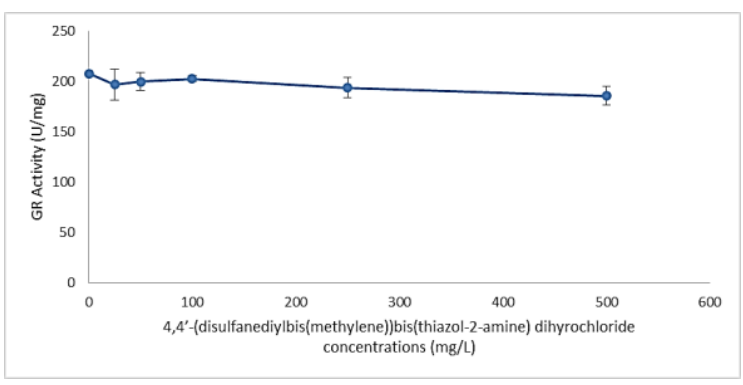

Figure 2. Effect of DMTA on GR activity.

\subsection{Effect of 2-amino-4-(chloromethyl)thiazole} hydrochloride on glutathione reductase activity

GR activities exposed to solutions of ACT from 0 to $500 \mathrm{mg} / \mathrm{L}$ were measured. Mean of GR activity and standard deviation values were given in Table 1. Activity-concentration graph was shown in Fig. 3. When Table 1 and Fig. 3 were examined, it was seen that there were no statistically significant changes in GR enzyme activities when compared to control group while ACT concentration increased $(p>0.05, n=3)$. The percent changes in GR activity by exposure of GR to 25, 50, 100, 250 and $500 \mathrm{mg} / \mathrm{L}$ ACT were calculated as $+0.98 ; 0.00$; $-0.49 ;-2,45$ and 0.00 respectively.

Table 1. Effect of DMTA and ACT 2-aminothiazole derivatives concentrations on GR activity.

\begin{tabular}{ccc}
\hline $\begin{array}{c}\text { 2-Aminothiazole Derivatives } \\
\text { Concentration }(\mathrm{mg} / \mathrm{L})\end{array}$ & $\begin{array}{c}\text { GR activity } \pm \text { standart deviation } \\
(\mathrm{U} / \mathrm{mg}) \text { for DMTA }\end{array}$ & $\begin{array}{c}\text { GR activity } \pm \text { standart deviation } \\
\text { (U/mg) for ACT }\end{array}$ \\
\hline 0 & $208 \pm 3 \mathrm{a}$ & $204 \pm 8 \mathrm{a}$ \\
\hline 25 & $197 \pm 15 \mathrm{a}$ & $206 \pm 12 \mathrm{a}$ \\
\hline 50 & $200 \pm 9 \mathrm{a}$ & $204 \pm 11 \mathrm{a}$ \\
\hline 100 & $203 \pm 3 \mathrm{a}$ & $203 \pm 6 \mathrm{a}$ \\
\hline 250 & $194 \pm 10 \mathrm{a}$ & $199 \pm 5 \mathrm{a}$ \\
\hline 500 & $186 \pm 9 \mathrm{a}$ & $204 \pm 3 \mathrm{a}$ \\
\hline
\end{tabular}




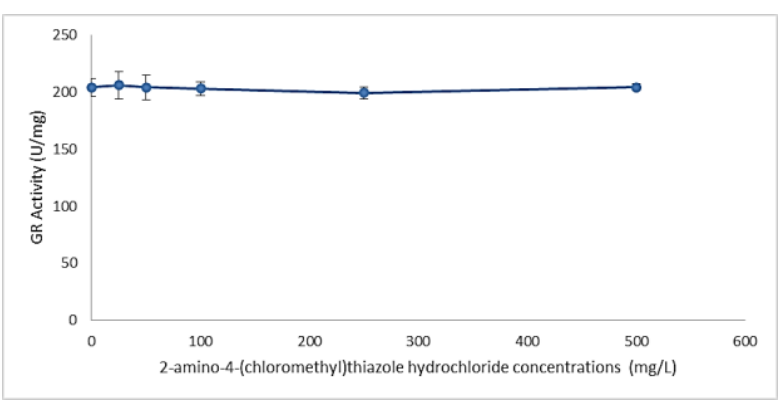

Figure 3. Effect of ACT on GR activity.

When we look at the literature, we did not find any direct studies on the effects of DMTA and ACT on GR activity. However, studies on the effects of 2aminothiazole derivatives or thiazole derivatives on other enzyme activities were found. Such as, 2aminothiazole derivatives act as inhibitors against kynurenine-3-hydroxylase and cyclin-dependent kinase enzymes [5]. Also, the 2-aminothiazole-4carboxamide compound was a novel class of inhibitors of serine / threonine protein kinase (CHK1) [12]. In another study, (4 - ((4- (4chlorophenyl) -2-thiazolyl) amino) phenol compound at a concentration of $10 \mu \mathrm{M}$ was a moderate inhibitor (15-25\% inhibition) in the experimental conditions for sphingosine kinase [13]. These result was similar like our findings about DMTA which DMTA caused a moderate inhibition (10.58\% inhibition at $500 \mathrm{mg} / \mathrm{L})$. Another study, 3- (5- (4- (benzyloxy) -3methoxyphenyl) -1- (4- (4-bromophenyl) thiazol2-yl) -4,5-dihydro-1H-pyrazol-3-yl) $\quad-2 \mathrm{H} \quad-$ chromen-2-one was shown to be a potential tyrosinase inhibitor [14].

\section{CONCLUSION}

DMTA is similar to GSSG in that it contains the disulfide bridge. DMTA may compete with GSSG to influence GR. DMTA has slightly inhibited GR $(10.58 \%$ inhibition at $500 \mathrm{mg} / \mathrm{L})$. ACT did not have any effect on GR because it did not contain disulfide bridge. As a result, we found that DMTA caused a moderate inhibition and ACT did not cause any inhibition. But ultimately, we didn't find any statistically significant changes on GR activities in the our work.

\section{REFERENCES}

[1]. Ghaemmaghami S., May B.C.H., Renslo A.R. and Prusiner S.B., Discovery of 2Aminothiazoles as Potent Antiprion Compounds, J. Virol., 84-7 (2010) 34083412.

[2]. Siddiqui H.L., Zia-Ur-Rehman M., Ahmad N., Weaver G.W. and Lucas, P.D., Synthesis and Antibacterial Activity of Bis[2-Amino-4Phenyl-5-Thiazolyl] Disulfides, Chem. Pharm. Bull., 55-7 (2007) 1014-1017.

[3]. Kesicki E.A., Bailey M.A., Ovechkina Y., Early J.V., Alling T., Bowman J., Zuniga E.S., Dalai S., Kumar N., Masquelin T., Hipskind P.A., Odingo J.O., Parish T., Synthesis and Evaluation of the 2-Aminothiazoles as AntiTubercular Agents, Plos One, 11-5 (2016) e0155209.

[4]. Lin P., Hou R., Wang H., Kang I. and Chen L., Efficient Synthesis of 2-Aminothiazoles and Fanetizole in Liquid PEG-400 at Ambient Conditions, J. Chin. Chem. Soc., 56-3 (2009) 455-458.

[5]. Kim K.S., Kimball S.D., Misra R.N., Rawlins D.B., Hunt J.T., Xiao H.Y., Lu S., Qian L., Han W-C., Shan W., Mitt T., Cai Z.W., Poss M.A., Zhu H., Sack J.S., Tokarski J.S., Chang C.Y., Pavletich N., Kamath A., Humphreys W.G., Marathe P., Bursuker I., Kellar K.A., Roongta U., Batorsky R., Mulheron J.G., Bol D., Fairchild C.R., Lee F.Y. and Webster K.R., Discovery of Aminothiazole Inhibitors of Cyclin-Dependent Kinase 2: Synthesis, XRay Crystallographic Analysis, and Biological Activities, J. Med. Chem., 45-18 (2002) 3905-3927.

[6]. Halliwell B., Gutteridge J. M. C., Free Radicals in Biology and Medicine. 3rd ed. New York: Oxford University Press, 1999; pp 143-144.

[7]. Deponte, M., Glutathione Catalysis and the Reaction Mechanisms of GlutathioneDependent Enzymes, Biochim. Biophys. Acta., 1830 (2013) 3217-3266. 
[8]. Karabıyık H., Kırılmış C., Karabıyık H., Geometry Dependence of Electron Donating or Accepting Abilities of Amine Groups in 4,4'Disulfanediylbis(Methylene)Dithiazol-2Amine: Pyramidal Versus Planar, J. Mol. Struct., 1141 (2017) 650-659.

[9]. Lowry O.H., Rosebrough N.J., Farr A.L., Randall R.J., Protein Measurement with the Folin Phenol Reagent, J. Biol. Chem., 193 (1951) 265-275.

[10].Carlberg I. and Mannervik B., Purification and Characterization of the Flavoenzyme Glutathione Reductase from Rat Liver, J. Biol. Chem., 250-14 (1975) 5475-5480.

[11].Karadag H., Bilgin R., Effect of Cyprodinil and Fludioxonil Pesticides on Human Superoxide Dismutase, Asian J. Chem., 22-10 (2010) 8147-8154.

[12].Huang X., Cheng C.C., Fischmann T.O., Duca J.S., Richards M., Tadikonda P.K., Reddy
P.A., Zhao L., Siddiqui M.A., Parry D., Davis N., Seghezzi W., Wiswell D., Shipps Jr G.W., Structure-Based Design and Optimization of 2-Aminothiazole-4-Carboxamide as a New Class of CHK1 Inhibitors, Bioorg. Med. Chem. Lett., 23 (2013) 2590-2594.

[13].Vogt D., Weber J., Ihlefeld K., Brüggerhoff A., Proschak E., Stark H., Design, Synthesis and Evaluation of 2-Aminothiazole Derivatives as Sphingosine Kinase Inhibitors, Bioorgan. Med. Chem., 22 (2014) 5354-5367. [14].Saeed A., Mahesar P.A., Channar P.A., Abbas Q., Larik F.A., Hassan M., Raza H., Seo S.Y., Synthesis, Molecular Docking Studies of Coumarinyl-Pyrazolinyl Substituted Thiazoles as Non-Competitive Inhibitors of Mushroom Tyrosinase, Bioorg. Chem., 74 (2017) 187-196. 